\title{
Fenomena Phone Snubbing pada Siswa Menengah Pertama
}

\author{
Meytikasari Dwijayanti*, Lutfi Fauzan, Elia Flurentin \\ Universitas Negeri Malang, Jl. Semarang No. 5 Malang, Jawa Timur, Indonesia \\ *Penulis korespondensi, Surel: mmeeyytikkaa@gmail.com
}

Paper received: 3-3-2021; revised: 24-3-2021; accepted: 28-3-2021

\begin{abstract}
In the midst of the Covid-19 pandemic, smartphones have become the main tool in online learning at all levels of education. This has an impact on the intensity of smartphone use in everyday life. This situation has led to a growing phone snubbing behavior and is not realized by individuals. Phone Snubbing as a phenomenon of excessive individual smartphone use shows a behavior that is ignorant and indifferent to the presence of people around. This behavior is characterized by being fixated on a smartphone that is held so that it can have positive and negative impacts in the social environment, especially in the personal and social fields of students. This descriptive qualitative research aims to describe information about the background and factors causing the phenomenon of phone snubbing behavior in students as well as recommendations for BK service strategies. Data analysis using the Miles and Huberman model. The validity of the research data was carried out by extending observations, increasing persistence and triangulating sources. The results showed 1) The background of phone snubbing behavior in junior high school students stated that the use of smartphones in the high category, namely an average of 6-10 hours per day, caused a high smartphone dependence. The situation of using smartphones when interacting with junior high school students is very diverse, including forms of avoidance, to get rid of boredom, the importance of activities with smartphones, and other needs that require a fast response. The reason for using a smartphone is to fulfill the interests of learning as well as for entertainment, maintaining communication with long distance friends. 2) Four factors that indicate phone snubbing behavior of junior high school students, namely nomophobia, interpersonal conflict, recognition of problems and self-isolation; 3) BK service strategy recommendations include guidance and counseling tailored to the needs.
\end{abstract}

Keywords: smartphone; phone snubbing; junior high school student; guidance and counseling

\begin{abstract}
Abstrak
Di tengah pandemi Covid-19, smartphone menjadi piranti utama dalam pembelajaran daring di semua jenjang pendidikan. Hal tersebut berdampak pada intensitas penggunaan smartphone dalam kehidupan sehari-hari. Keadaan tersebut memunculkan perilaku phone snubbing semakin berkembang dan tidak disadari oleh individu. Phone Snubbing sebagai fenomena penggunaan smartphone individu yang berlebihan menunjukan perilaku abai dan tak acuh atas kehadiran orang di sekitar. Perilaku ini ditandai dengan terpaku pada smartphone yang digenggam sehingga dapat menimbulkan dampak positif dan negatif dalam lingkungan sosial, khususnya pada bidang pribadi dan sosial siswa. Penelitian kualitatif deskriptif ini bertujuan untuk menjabarkan informasi tentang latar belakang dan faktor penyebab fenomena perilaku phone snubbing pada siswa serta rekomendasi strategi layanan BK. Analisis data menggunakan model Miles \& Huberman. Keabsahan data penelitian dilakukan dengan cara perpanjangan pengamatan, peningkatan ketekunan dan triangulasi sumber. Hasil penelitian menunjukkan 1) Latar belakang perilaku phone snubbing pada siswa SMP menyatakan bahwa penggunaan smartphone dengan kategori tinggi yaitu rata-rata 6-10 jam perhari hingga menyebabkan ketergantungan smartphone yang juga tinggi. Situasi penggunaan smartphone saat interaksi pada siswa SMP sangat beragam, meliputi bentuk penghindaran, untuk mengusir rasa bosan, adanya kepentingan yang terdapat dalam aktivitas dengan smartphone, dan keperluan yang lainnya yang membutuhkan fast response. Alasan penggunaan smartphone untuk memenuhi alih-alih kepentingan belajar juga untuk mencari hiburan, menjaga komunikasi dengan teman jarak jauh. 2) Empat faktor yang mengindikasikan perilaku phone snubbing siswa SMP yaitu nomophobia, konflik interpersonal, pengakuan masalah dan isolasi diri; 3) Rekomendasi strategi layanan BK meliputi bimbingan dan konseling yang disesuaikan dengan kebutuhan.
\end{abstract}


Kata kunci: smartphone; phone snubbing; siswa SMP; bimbingan dan konseling

\section{Pendahuluan}

Dunia telah memasuki era globalisasi (Abdillah, 2019). Perkembangan teknologi informasi sekarang ini semakin pesat. Perkembangan teknologi informasi (TI) dan jejaring internet sekarang ini membuat banyaknya kemunculan digitalisasi (Salim, et al., 2020). Dewasa ini, smartphone sangat dibutuhkan oleh semua kalangan dan bahkan menjadi barang perlengkapan primer karena praktis dibawa kemana-mana dan dapat memudahkan pekerjaan seseorang. Keadaan di lapangan menunjukkan seseorang akan merasa kebingungan bila jauh dari smartphone, apalagi disediakan fasilitas mulai dari chat, video call, browser, game dan berbagai aplikasi lainnya sehingga seseorang dapat menjelajahi dunia hanya melalui benda kotak dalam genggaman. Penggunaan teknologi sangat menjawab kebutuhan dan memudahkan pekerjaan, khususnya pasca pandemi Covid-19 melanda diberbagai belahan bumi.

Situasi saat ini lembaga pendidikan dituntut untuk berinovasi dalam memberikan kemasan dalam proses pembelajaran karena bagaimana pun juga kegiatan belajar mengajar harus tetap berjalan sebagai mana mestinya, sehingga pembelajaran daring (dalam jariangan atau online) menjadi salah satu inovasi yang diupayakan pemerintah untuk melangsungkan bidang pendidikan (Jamaluddin, 2020). Distance education menjadi pilihan terakhir untuk tetap melakukan pembelajaran dengan kondisi penyebaran virus Covid-19 yang semakin meluas (Oranburg, 2020). Penelitian oleh Zhong (2020) menyebutkan sistem daring ini sebagai alternatif kegiatan belajar tetap berjalan ditengah maraknya wabah virus Covid-19 di Indonesia.

Salah satu piranti utama dalam keberhasilan pelaksanaan pembelajaran daring ini adalah smartphone, ponsel cerdas yang dapat memberikan fasilitas siswa untuk belajar di rumah secara online terhubung dengan jaringan internet. Hasil riset yang dilakukan oleh Daulay (2020) menyatakan pengguna smartphone di Indonesia mencapai 83.18 juta, sehingga Indonesia menduduki posisi ketiga besar dalam Asia Pasifik. Sebesar 93\% kalangan remaja medominasi sebagai pengguna smartphone, tepatnya remaja yang sedang duduk dibangku SMP sampai dengan SMA usia 12-18 tahun. Kecanggihan smartphone dapat dimanfaatkan secara positif maupun negatif tergantung oleh penggunanya. Hal senada juga dinyatakan bahwa kecanggihan smartphone menghantarkan kemudahan bagi anak untuk melatih tingkat kreativitas dan kecerdasan (Novitasri \& Khotimah, 2016). Fungsi smartphone sangat membantu pada situasi pandemi Covid-19 ini, maka tidak heran kebanyakan siswa seringkali menghabiskan waktu sehari-hari untuk mengakses smartphone yang dimiliki. Sayangnya, siswa memanfaatkan kehadiran smartphone sebagai arena hiburan, berdasarkan keadaan di lapangan siswa menyatakan lebih asyik main games daripada membuka google classroom (Observasi Peneliti, 2020).

Selaras dengan Rachman (dalam Alia \& Irwansyah, 2018) berhasil memaparkan bahwa terdapat hasil prestasi belajar individu yang menurun karena penggunaan teknologi digital, selain itu Alia \& Irwansyah menyebutkan dampak lainnya meliputi : aktivitas fisik yang terbatas berpengaruh pada tumbuh kembang individu dan seputar kesehatan yang terganggu, seperti mata merah dan sebagainya. Berdasarkan observasi di lapangan peneliti menemukan kenyataan tersebut. hingga pada masa pandemi orang tua sekarang sering 
mengeluh terkait pemakaian smartphone individu sehingga telah memberikan gangguan alhasil proses belajar terhambat karena waktu tersita akibat aktivitas dengan smartphone.

Berbicara mengenai penggunaan smartphone, mayoritas telah menjadi bagian dari kegemaran individu. Hal tersebut diperkuat oleh pendapat Cooper (2000), mengenai perilaku ketergantungan pada suatu hal yang disenangi. Sama halnya dengan keadaan siswa yang menjadi candu dengan aktivitas yang dilakukan pada smartphone atas berbagai kemudahan yang diberikan. Namun sayangnya, perilaku phone snubbing (phubbing) yang muncul menjadi citra buruk individu di mata orang lain.

Berbagai permasalahan muncul karena meningkatkan penggunaan smartphone, seiring dengan hal tersebut juga turut melahirkan fenomena phubbing. Secara konsep "phubbing" dimaknai sebagai perilaku menghina yang ditunjukkan dengan tidak memperdulikan orang lain dalam interaksi sosial dan berfokus pada satu interaksi individu dengan smartphone yang dimiliki (Haigh, 2015). Menurut Robert (2016) phone snubbing terdiri dari kata "phone" yang berarti ponsel sekarang sering disebut smartphone dan "snubbing" yang artinya tidak peduli dengan konotasi menghina. Fenomena demikian menganggap bahwa individu yang fokus atau berkonsentrasi pada ponselnya menjadi melecehkan bagi orang disekelilingnya. Ramadhani (2020) menyatakan bahwa penggunaan smartphone yang berlebihan di kehidupan sosial akan mengakibatkan kecanduan. Individu yang mengalami kecanduan, tentu akan merasa cemas jika terlalu lama tidak mengakses smartphone sehingga individu memiliki kecenderungan perilaku phone snubbing (phubbing).

Menurut Sulistyaningsih (dalam Vetsera, 2019), penggunaan smartphone ini dijuluki dengan sebutan "generasi merunduk" karena ditengah masyarakat individu sebagai pelaku cenderung lebih asyik dengan dunia dalam genggaman daripada teman bicara yang berada dihadapannya. Dalam sebuah jurnal yang dipublikasikan pada laman www.ncbi.nlm.nih.gov NCBI (National Center forBiotechnology Information) yang berjudul Determinants of Phubbing, Which is the Sum of ManyVirtual Addictions: A Structural Equation Model bahwa phubbing memiliki struktur multi dimensi, meliputi : kecanduan ponsel, kecanduan internet, kecanduan media sosial dan kecanduan game. Karadag, dkk (2015) mengungkapkan mengenai macam-macam kecanduan tersebut memberikan sumbangsih pada pembentukan perilaku phone snubbing dalam diri individu.

Menurut Chotpitayasunondh \& Douglas (2016) juga menyebutkan kecanduan penggunaan ponsel berangkat dari efek candu untuk mengakses internet, dan FoMo (Fear of Missing Out). Berdasarkan penelitian yang telah dilakukan oleh Chotpitayasunondh \& Douglas (2018) terdapat empat faktor yang menjadi petunjuk ketika seseorang melakukan phone snubbing. Jabaran faktor tersebut antara lain : 1) Nomophobia (No Mobile Phone Phobia), fenomena yang terjadi sebagai akibat rasa takut berjauhan dengan smartphone. 2) Isolasi Diri (Self Isolation), individu sengaja membatasi diri dengan lingkungan dan lebih berkonsentrasi pada smartphone. 3) Pengakuan Masalah (Problem Acknowledgement), kesadaran individu terkait perilaku yang dilakukan ketika berada dalam lingkungan sosial, seperti tahu bahwa seseorang tidak suka ketika individu fokus dengan smartphone dibandingkan kualitas obrolan 4) Konflik Interpersonal (Intepersonal Conflict), munculnya gangguan atau masalah yang dirasakan antara diri sendiri dengan orang lain akibat penggunaan smartphone. 
Peneliti memotret bahwa fenomena phubbing akan menimbulkan masalah bagi individu pada bidang pribadi dan sosialnya, sehingga peneliti akan menunjukkan perlunya keberadaan peran BK dalam membantu mengentaskan individu dari permasalahan yang dialami dalam fenomena phubbing guna mendapatkan layanan baik bimbingan atau konseling. Selain menimbulkan hambatan pada ranah pribadi dan sosial, capaian pada penyesuian diri dan kelainan tingkah laku. Sesuai dengan Standar Kompetensi Kemandirian Peserta Didik (SKKPD) terkait dengan kesadaran tanggung jawab sosial individu menjadi titik berat peran konselor untuk membantu individu memenuhi aspek tersebut guna menjadi pribadi yang sehat dan utuh diterima oleh lingkungan sosial.

Berdasarkan hal tersebut peneliti tertarik untuk mengetahui informasi tentang fenomena phone snubbing ditengah masa pandemi Covid-19. Fenomena tesebut akan dijabarkan secara deskriptif sesuai dengan latar belakang yang diperoleh selama di lapangan hasil tinjauan dari empat faktor phone snubbing pada siswa sekolah menengah pertama. Selain itu peneliti dapat memberikan rekomendasi terkait rancangan strategi layanan bimbingan dan konseling dalam mengatasi fenomena ini yang terjadi pada siswa sekolah menengah pertama sekaligus implikasi bimbingan dan konseling menyikapi perkembangan fenomena di lingkungan sosial.

\section{Metode}

Penelitian ini menggunakan pendekatan kualitatif deskriptif yang bertujuan untuk menjabarkan informasi tentang latar belakang dan faktor penyebab fenomena perilaku phone snubbing pada siswa serta rekomendasi strategi layanan bimbingan dan konseling. Subjek dipilih dengan teknik purposive sampling, sesuai kriteria yang telah ditentukan yaitu (1) Siswa SMP Negeri 23 Kota Malang, baik laki-laki maupun perempuan, (2) Penggunaan smartphone berlebihan, (3) Subjek bersedia berpartisipasi sampai dengan penelitian selesai. Fenomena Phone Snubbing diteliti dari sumber data primer berupa perolehan dari hasil observasi secara terstruktur secara partisipasi pasif, wawancara mendalam terhadap 2 orang konselor dan 8 orang siswa secara tatap muka dan 3 orang tua siswa secara daring, dan dokumentasi berupa foto kegiatan wawancara dengan subjek dan aktivitas siswa ketika menggunakan smartphone di lingkungan sosial. Analisis data menggunakan model Miles \& Huberman. Keabsahan data penelitian dilakukan dengan cara perpanjangan pengamatan, peningkatan ketekunan dan triangulasi sumber.

\section{Hasil dan Pembahasan}

Berdasarkan hasil pemerolehan data dari kegiatan wawancara mendalam dan observasi sekaligus dokumentasi, peneliti mendapatkan berbagai informasi yang akan menggambarkan latar belakang perilaku phone snubbing ini di kalangan siswa SMP Negeri 23 Malang, sebagai berikut :

\subsection{Latar Belakang Perilaku Phone Snubbing di SMP Negeri 23 Malang}

\subsubsection{Frekuensi Penggunaan Smartphone Saat Berinteraksi}

Menurut Rakhmawati, dkk (2020) meneliti bahwa anak-anak yang lahir di era sekarang ini identik tidak dapat dipisahkan dari smartphone akhirnya memilih untuk asyik memainkan smartphone dibandingkan berinteraksi dengan lingkungan. Pernyataan tersebut menguatkan keadaan di lapangan, siswa mengaku memiliki kebiasaan berlama-lama 
mengakses dan menggunakan smartphone sehari-hari hal tersebut dikarenakan rasa bosan, kesepian yang mengganggu, rasa tidak nyaman bisa berjauhan dengan smartphone hingga keperluan penting untuk melakukan pembelajaran daring di tengah masa pandemi ini.

\subsubsection{Situasi Saat Menggunakan Smartphone}

Ada beberapa siswa yang menyatakan bahwa menggunakan smartphone ketika ada urusan penting dan yang diprioritaskan oleh masing-masing individu, yaitu untuk hiburan, komunikasi dan akademik. Setiap siswa sebagai subjek terteliti memiliki alasan yang berbeda dalam penggunaan smartphone. Sehubungan dengan hal tersebut, berbeda pula situasi dan kondisi siswa menggunakan smartphonenya ketika berada di lingkungan sosial, siswa dominan untuk menanggapi telepon penting, notifikasi yang terdapat dalam smartphone. Di lapangan peneliti juga menemukan situasi seperti situasi makan diatas meja makan, acara keluarga bahkan perbincangan yang terdiri dari dua orang saja siswa mayoritas pernah menggunakan smartphone dalam situasi-situasi tersebut.

\subsubsection{Alasan Menggunakan Smartphone Saat Berinteraksi}

Alasan ini berkaitan dengan situasi subjek saat menggunakan smartphone. Situasi yang mendesak penting dan memerlukan respon menjadikan alasan tersendiri bagi individu untuk mengakses smartphonenya walau sedang dalam obrolan yang terjadi ketika mereka terdapat dalam lingkungan sosial. Subjek sadar bahwa alasan tersebut mengarah pada mementingkan kepentingan sendiri.

\subsubsection{Saat berada jauh dari Smartphone}

Dalam penelitian Asif \& Rahmadi (2017) menyatakan bahwa ada hubungan antara tingkat kecanduan gadget dengan perilaku remaja berusia 11-12 tahun. Dalam penelitiannya dijelaskan bahwa sejak menggunakan gadget, anak-anak atau remaja ketika di rumah menjadi sulit untuk berkomunikasi, tidak peduli dan kurang menanggapi ketika orang tua mengajak untuk berbicara. Ini dapat menyebabkan kesenjangan antara anak dan orang tua mereka, lingkungan mereka, bahkan rekan-rekan mereka. Kemudian ketika menggunakan gadget, ketika mereka terbuang untuk terus bermain game. Ini akan menghambat proses pengenalan pada anak-anak dan akan menyebabkan ketergantungan pada gadget.

\subsubsection{Indikasi Kecanduan Smartphone}

Indikasi kecanduan smartphone menjadi salah satu aspek penting munculnya perilaku phone snubbing. Pengkajian yang digagas oleh Griffiths (dalam Adi, 2018) menggali keadaan individu yang merasakan kecanduan sehingga lupa waktu, bahkan individu tidak peduli dengan pergerakan dunia luar dan keberadaan orang lain disekeliling. Subjek mengutarakan menyadari bahwa dirinya telah digolongkan sebagai pribadi yang merasakan kecanduan atau ketergantungan dengan smartphone sehingga sering kali ketika dalam lingkungan sosial ia asyik dengan aktivitas dalam smartphonenya untuk membalas chatting melalui WhatsApp, bermain games, menonton YouTube, akses aplikasi video lainnya. 


\subsubsection{Perilaku Phone Snubbing}

Kajian dilakukan oleh Pinchot, et al (2010) menyatakan bahwa HP atau smartphone bahwa perilaku komunikasi yang terjadi dalam kehidupan sehari-hari telah berubah. Orang tidak lagi merasa tabu jika harus bermasalah dengan ponselnya ketika pemakaman, atau saat makan malam. Pada akhirnya penampilan jargon membawa jauh dan jarak dekat menjadi sebuah hal yang normatif dipandang oleh penggunanya. Orang-orang lebih sibuk dengan smartphone dibandingkan harus berinteraksi dengan orang lain atau membangun hubungan dengan lingkungan sosial. Inilah titik fokus perilaku phone snubbing menjadi kebiasaan baru yang menekankan dengan hubungan bersama orang lain.

\subsection{Faktor Perilaku Phone Snubbing di SMP Negeri 23 Malang}

\subsubsection{Nomophobia}

Nomophobia merupakan sebuah sindrom mengenai rasa takut individu apabila tidak mengakses smartphone yang dimiliki, sehingga individu tidak pernah lepas atau pisah dengan smartphone dalam segala keadaan. Penderita nomophobia ini cenderung menggunakan media sosial sebagai alat komunikasi, perasaan cemas akan muncul dan rasa tidak nyaman dirasakan oleh individu. Individu yang kurang berhati-hati dalam melakukannya dapat melupakan kehadiran teman-teman fisik di sekitar individu (Rabathy, 2018). Hal tersebut memperkuat bagaimana individu yang terindikasi phone snubbing memiliki keterkaitan dengan smartphone bahkan akan mengalami kecemasan yang berlebih ketika tidak memegang dan mengakses smartphonenya mengarahkan pada fenomena yang dikaji oleh peneliti.

\subsubsection{Konflik Interpersonal}

Perkembangan masa diikuti oleh kemajuan alat sehari-hari menimbulkan masalah bagi penggunanya apabila mereka salahgunakan. Gadget yang tidak sengaja menarik perhatian individu dan membuat ketagihan permainan untuk bermain, memecahkan peraturan sekolah, melihat laman lucah dan membuat perubahan tingkah laku pelajar (Hana, Wardani, \& Arief, 2017). Pernyataan tersebut memperkuat adanya bahwa smartphone kini membawa dampak yang cukup besar dalam diri individu, bahkan dapat menyebabkan individu memiliki masalah dengan orang lain. Munculnya perilaku phone snubbing ini dapat ditandai dengan adanya konflik batin atau kondisi yang tidak baik antara subjek terteliti dengan orang lain.

\subsubsection{Isolasi Diri}

Dalam hubungan interaksi di lingkungan sosial, pilihan individu untuk menyibukkan diri mengakses atau bermain dengan smartphonenya dilatar belakangi oleh rasa keinginan membatasi diri agar tidak terlibat dalam sebuah percakapan atau interaksi yang terjadi didepan mata. Isolasi diri ini juga dimaknai sebagai pembatas individu untuk berinteraksi, apalagi di masa pandemi individu semakin memahami maksud isolasi diri. Turnbull (2010) menunjukkan bahwa seseorang yang menghabiskan banyak waktu mengakses Internet, maka ia hanya memiliki sedikit waktu untuk berkomunikasi dengan orang lain secara nyata di lingkungan sosial. 


\subsubsection{Pengakuan masalah}

Setiap tindakan yang dilakukan individu dapat ditandai sebab-akibatnya. Beberapa individu akan menyampaikan maksud dari apa yang mereka lakukan. Pengakuan masalah ini menjadi salah satu faktor perilaku phone snubbing, karena individu menyadari bahwa dirinya sedang dalam keadaan yang tidak baik sehingga memilih untuk dekat dengan smartphonenya. Artinya individu memberikan persetujuan dan sengaja mengabaikan lawan bicara dan lingkungan sekitar dan memilih untuk memainkan smartphone yang dimiliki.

\subsection{Rekomendasi Strategi Layanan Bimbingan dan Konseling terhadap Fenomena Phone Snubbing}

Terdapat rekomendasi strategi layanan bimbingan dan konseling terhadap fenomena phone snubbing berkaitan dengan kesadaran tanggung jawab sosial pada individu, sebagai berikut pada layanan dasar terdapat bimbingan klasikal dan kelompok dengan topik pilihan dalam rangka memberikan layanan informasi yang edukatif bagi seluruh siswa. Kemudian pada layanan perencanaan individual konselor dapat membantu subjek terteliti untuk menilai kelebihan dan kekurangan masing-masing dan direfleksikan dalam fenomena phone snubbing. Selanjutnya dalam layanan responsif, bagi subjek terteliti juga perlu diberikan fasilitas konseling dengan menggunakan pendekatan CBT atau dapat disesuaikan dengan kebutuhan siswa. Dan pada bagian dukungan sistem dapat dilakukan melalui dua kegiatan, meliputi kolaborasi dengan orang tua serta penelitian untuk mengkaji lebih banyak fenomena phone snubbing dan fenomena yang terkini dan melakukan pengembangan pada program bimbingan dan konseling agar tepat sasaran dan menjawab kebutuhan siswa di sekolah.

\section{Simpulan}

Fenomena phone snubbing tidak dapat dianggap sebagai kebiasaan yang sepele di tengah berkembangnya siswa SMP dengan usia remaja yang dipenuhi dengan tantangan dan pengaruh di lingkungan. Kemunculan perilaku phone snubbing ini ditandai dengan enam latar belakang, meliputi (1) Frekuensi menggunakan smartphone saat berinteraksi, (2) Situasi menggunakan smartphone saat berinteraksi, (3) Alasan menggunakan smartphone saat berinteraksi, (4) Saat berada jauh dari smartphone, (5) Indikasi kecanduan smartphone dan (6) Tanda-tanda phone snubbing. Dari keenam latar belakang tersebut memicu perilaku phone snubbing dilakukan dan dialami oleh subjek terteliti. Hal tersebut diperkuat dengan adanya indikasi dari faktor phone snubbing yang terdapat empat faktor, yaitu nomophobia, konflik interpersonal, pengakuan masalah dan isolasi diri. Motif tersebut menjadi faktor phone snubbing dilakukan dan dialami oleh mayoritas individu yang menjadi subjek terteliti. Sebagian besar mengarah pada faktor nomophobia, namun setiap subjek terteliti mengalami ke empat faktor tersebut dengan porsi yang berbeda-beda.

\section{Daftar Rujukan}

Abdillah, L. A. (2019). Analisis Aplikasi Mobile Transportasi Online Menggunakan User Experience Questionnaire pada Era Milenial dan Z'. Jurnal Sistem Informasi Bisnis (JSINBIS), 9(2), 204-211.

Adi, P. R. (2018). Hubungan Antara Kecanduan Gadget (Smartphone) Dengan Empati Pada Mahasiswa Fakultas Psikologi Universitas Muhammadiyah Surakarta. (Doctoral dissertation, Universitas Muhammadiyah Surakarta). 
Asif, A. R., \& Rahmadi, F. A. (2017). Hubungan tingkat kecanduan gadget dengan gangguan emosi dan perilaku remaja usia 11-12 tahun (Doctoral dissertation, Faculty of Medicine).

Chotpitayasunondh, V., \& Douglas, K. M. (2016). How "phubbing" becomes the norm: The antecedents and consequences of snubbing via smartphone. Computers in Human Behavior, 63, 9-18.

Chotpitayasunondh, V., \& Douglas, K. M. (2018). Measuring phone snubbing behavior: Development and validation of the Generic Scale of Phubbing (GSP) and the Generic Scale of Being Phubbed (GSBP). Computers in Human Behavior, 88, 5-17.

Cooper, A. (2000). Seks Maya: The Dark Side of the Force: A Special Issue of The Jurnal Sexual Addiction \& Compulsivity. Philadelphia: GH Buchanan.

Daulay, R. S., Pulungan, H., Noviana, A., \& Hurhaliza, S. (2020). Manfaat Teknologi Smartphone dalam kegiatan Pembelajaran Pendidikan Islam Di Masa Pandemi Corona-19. Al-Ulum: Jurnal Pendidikan Islam, 1(1).

Haigh, A. (2015). Stop phubbing.

Jamaluddin, D. (2020). Pembelajaran Daring Masa Pandemik Covid-19 Pada Calon Guru : Hambatan, Solusi dan Proyeksi.

Karadağ, E., Tosuntaş, Ş. B., Erzen, E., Duru, P., Bostan, N., Şahin, B. M., ... Babadağ, B. (2015). Determinants of phubbing, which is the sum of many virtual addictions: A structural equation model. Journal of Behavioral Addictions, 4(2), 60-74.

Novitasari, W., \& Khotimah, N. (2016). Dampak penggunaan gadget terhadap interksi sosial anak usia 5-6 tahun. Paud Teratai, 5(3).

Pinchot, J., Paullet, K., \& Rota, D. (2011). How mobile technology is changing our culture. Journal of Information Systems Applied Research, 4(1), 39.

Rabathy, Q. (2018). Nomophobia Sebagai Gaya Hidup Mahasiswa Generasi Z. LINIMASA: JURNAL ILMU KOMUNIKASI, 1(1).

Ramadhani, I. R., Fathurohman, I., \& Fardani, M. A. Efek Penggunaan Smartphone Berkelanjutan pada Masa Pandemi Covid-19 terhadap Perilaku Anak. Jurnal Amal Pendidikan, 1(2), 96-105.

Roberts, J. A., \& David, M. E. (2016). My life has become a major distraction from my cell phone: Partner phubbing and relationship satisfaction among romantic partners. Computers in human behavior, 54, 134-141.

Salim, S., Basri, A. M., Husain, D. L., Hidayah, A. N., \& Nurhayati, N. (2020). The Use of Digital Literacy in Higher Education. AL-ISHLAH: Jurnal Pendidikan, 12(1), 52-66.

Sulistyaningsih, R. (2016). Kisah Dibalik Setiap Perhentian. Jakarta : Elec Media Komputindo.

Turnbull, J. (2010). Oxford Advanced Learner's Dictionary. New York: Oxford.

Zhong, R. (2020). The Coronavirus Exposes Education's Digital Divide. 